
v4i1.2795

\title{
The Percentage of Epiphytes Cover on The Seagrass Beds in Sepanjang Beach, Indonesia
}

\author{
Vina Listiawati, Siti Naily Rohmah, Dheny Choirul Alfan \\ Department of Biology Education, Universitas Muhammadiyah Surakarta 57102 Indonesia \\ e-mail: v1656@ums.ac.id
}

\begin{abstract}
Seagrasses are foundation plant species as they not only create their own habitat but also for other marine organisms. In estuarine and marine environments, they form beds and their leafy structure are the excellent substrate for the epiphytes. In this study, we aimed to investigate the percentage cover of epiphytes on the seagrass beds in Sepanjang Beach, Indonesia. 5 transect lines with $20 \mathrm{~m}$ in length with the $50 \times 50 \mathrm{~cm}$ quadrat at the interval of $5 \mathrm{~m}$ were placed at the perpendicular angle to the shoreline. These transects were positioned from the furthermost of the western part to the middle part of the beach, represented the gradation level of human activities. The result showed that the percentage cover of epiphytes was significantly higher on the middle part of the beach compared to the side of the beach. This present study suggest that human activities could lead to the increasing of epiphytes cover on the seagrass beds.
\end{abstract}

Keywords: epiphytes cover, seagrass beds, ecological assessment, Sepanjang Beach

\section{Introduction}

Seagrass beds can be found in estuarine and marine environments on Earth and are mostly found in the intertidal zone up to about $50 \mathrm{~m}$ depth as they need light for photosynthesis (Long et al., 1996). Seagrass beds are economically important because they support the various commercial fisheries stocks. They also often called as foundation plant species as they create habitat modifications to be more suitable for themselves and their surroundings. Seagrass beds provide habitat for many marine organisms, such as sea turtles, dugong, and various fishes due to its leafy underwater canopy. They also provide substrates for the growth of epiphytesorganisms that usually grow on plants.

The epiphytes of seagrass are one of the important components of seagrass beds ecosystem (Borowitzka et al., 2006). They are autotrophic organisms, thus it has an essential role as primary producers in seagrass beds. Several studies revealed that it can comprise up to $37 \%$ of the total of primary production on Thalassia hemprichii beds in Papua New Guinea (Heijs, 1984). They also play a role as carbonate sediment formers because one of the common epiphytes of seagrasses is calcareous red algae (Patriquin, 1972). In addition, the seagrasses epiphytes also contribute to the nutrient cycling in seagrass beds as it can uptake the ammonium from the seawater (Cornelisen and Thomas, 2002).

The epiphytes cover often included in the monitoring of seagrass meadows conditions (Tanner et al., 2014). Thus, it can be used as a tool to assess the healthiness of a seagrass ecosystem. This study aimed to investigate the percentage cover of epiphytes on seagrass beds of Sepanjang Beach, Indonesia. The seagrass beds are found on that particular beach near the shoreline.

\section{Materials And Methods}

Sepanjang Beach, located in Gunungkidul, Indonesia was choosed as the sampling site as it has seagrass beds in its area. This study was conducted in July 2018 during the low tide condition when the seawater levels were $1-10 \mathrm{~cm}$. A $20 \mathrm{~m}$ of five transect lines (A-E) were placed perpendicular to the shoreline, respectively. 
The transect A was placed in the furthest part (western side) of the beach where the human activities were considered on the lowest level, while the Transect $\mathrm{E}$ was placed in the middle part of the Sepanjang Beach shoreline and considered as the part of highest level human activities (Figure 1). The seawater temperature, $\mathrm{pH}$, and salinity were measured to determined the water quality of the sampling site.

At the right side of the transect line, a 50 x $50 \mathrm{~cm}$ quadrat was putted at the interval of $5 \mathrm{~m}$. These quadrats were used to assess the percentage cover of epiphytes on seagrass beds. Thus, quadrats without the seagrass cover were only were excluded from the assessment. The total percentage of epiphytes cover on each quadrat was calculated by following McKenzie et al. (2001):

where:

EC : Total epiphytes cover (\%)

EB : Epiphytes cover on the seagrass leaf blades (\%)

EQ : Epiphytes cover on the quadrat (\%)

The data will be analysed by using oneway ANOVA to examine the impact of transect locations on the percentage of epiphytes cover. A post-hoc test will be conducted if there was a significant difference on the result.

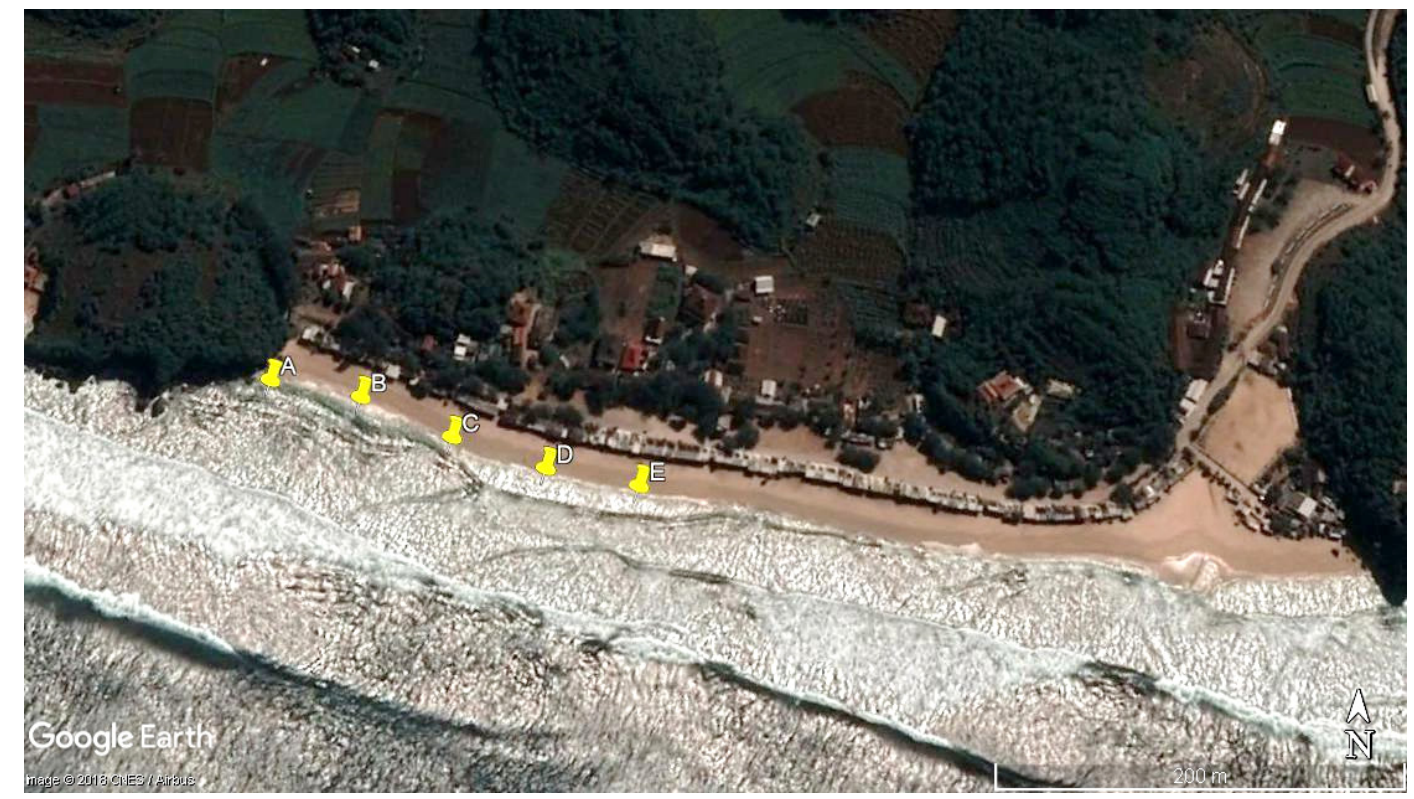

Figure 1. The location of the sampling sites (transects) in Sepanjang Beach

\section{RESULTS AND DISCUSSION}

The seagrass ecosystem in Sepanjang Beach is monospecific Thalassia hemprichii beds. The water quality parameters of this ecosystem was presented in Table 1. The epiphytes mostly attached to the leaf blades as the belowground part is mostly covered by the sandy sediment. The result showed that the epiphytes cover has different mean of value depend on the transect locations, as it increase from the transect $A$ to the transect $\mathrm{E}$. The transect $\mathrm{A}$, as the furthest sampling location on the western part of the beach, has the lowest of epiphytes cover. In contrast, the transect $\mathrm{E}$ which placed in the middle part of the beach, has the greatest value of the percentage of epiphyte cover (Figure 2). 
Tabel 1. Water quality parameters in Sepanjang Beach

\begin{tabular}{ccc}
\hline Temperature $\left({ }^{\circ} \mathrm{C}\right)$ & $\mathrm{pH}$ & Salinity $(\mathrm{ppt})$ \\
\hline 22 & 7 & 30 \\
\hline
\end{tabular}

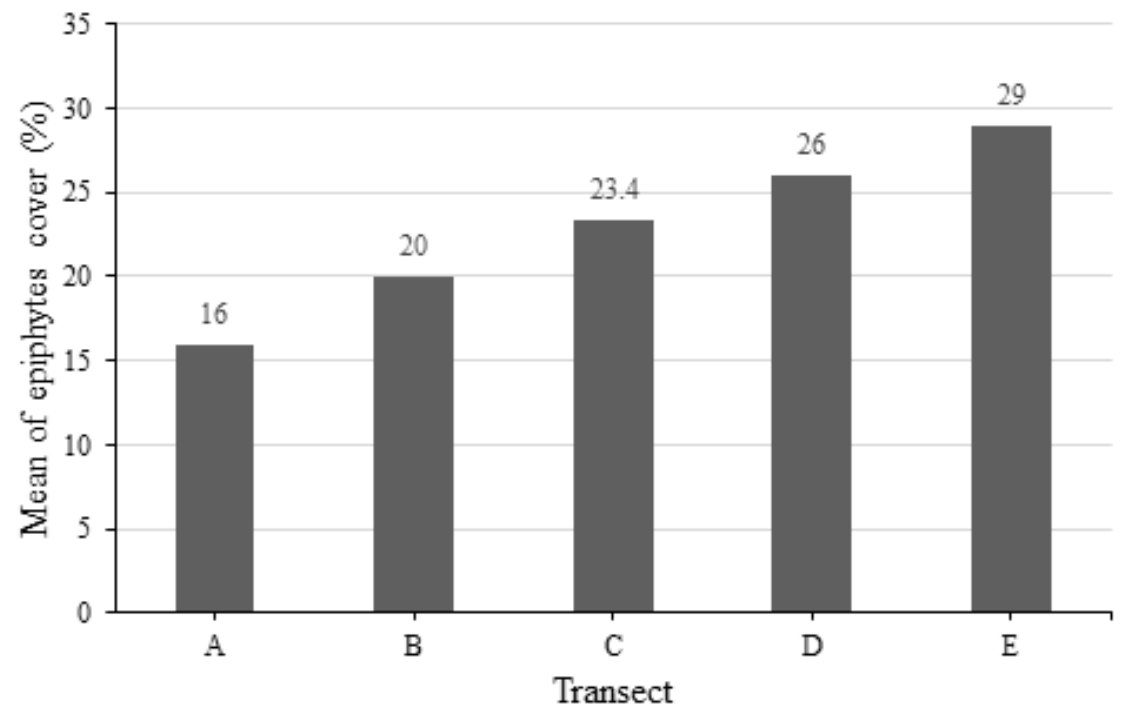

Figure 2. The percentage of epiphytes cover in Sepanjang Beach

A one-way ANOVA showed that the effect of transect locations on the percentage of epiphytes cover was significantly different between groups $[\mathrm{F}(4,18)=3.388, p=0.031]$ (Table 2). A Bonferroni post-hoc test revealed that the percentage of epiphytes cover was significantly higher at the $\mathrm{p}<0.05$ level in Transect $\mathrm{E}(\mathrm{M}=29, \mathrm{SD}=4.18)$ compared to Transect A $(M=16, S D=7.12)$ (Table 3$)$.

Tabel 2. One-way ANOVA of the percentage of epiphytes cover by the transect locations

\begin{tabular}{cccccc}
\hline Source & $d f$ & $S S$ & $M S$ & $F$ & $p$ \\
\hline $\begin{array}{c}\text { Between } \\
\text { groups }\end{array}$ & 4 & 455.67 & 113.917 & 3.388 & 0.031 \\
$\begin{array}{c}\text { Within } \\
\text { groups }\end{array}$ & 18 & 605.20 & 33.622 & & \\
Total & 22 & 1060.87 & & & \\
\hline
\end{tabular}

Table 3. The percentage of epiphytes cover in Sepanjang Beach (Mean \pm SD)

\begin{tabular}{ccccc}
\hline \multicolumn{5}{c}{ Transect } \\
\hline A & B & C & D & E \\
\hline $16 \pm$ & $20 \pm$ & $23.4 \pm$ & $26 \pm$ & $29 \pm$ \\
$7.12^{\mathrm{a}}$ & $6.34^{\mathrm{a}}$ & $5.94^{\mathrm{a}}$ & $5.48^{\mathrm{a}}$ & $4.18^{\mathrm{b}}$ \\
\hline
\end{tabular}

Note: The different alphabet letter indicated a significantly difference value $(p<0.05)$.
Epiphytes cover on the seagrass beds is influenced by succession and seasonality, the physical environment, and organismal interactions. The new species of epiphytes will be recruit to the seagrass beds due to the local hydrodynamics over time (Heijs, 1984). The physical environment, such as light, temperature, and nutrients also influence the epiphytes distribution on the seagrass ecosystem. Light is the key influence as the epiphytes need it for photosynthesis. This physical factor will be strongly correlated with the seawater temperature and nutrient availability to influence the epiphytes growth as it usually changed seasonally (Jacobs et al., 1983).

The change in the conditions of local environment also affect the growth of epiphytes in seagrass beds. Various human activities especially tourism was the source of stress and disturbance for seagrass ecosystems (Herrera-Silveira et al., 2010). This study showed that percentage of epiphytes cover was gradually increase from the western part to the middle part of the beach where the visitors usually concentrated in that particular area. The high percentage of epiphytes cover was 
likely due to the damaged of this habitat as the visitor usually trampling on the seagrass beds.

The seagrass biomass was negatively correlated with the intensity and duration of the trampling as the seagrass cover decline due to the light and heavy trampling and could not completely recovered (Eckrich and Holmquist, 2000). It suggest that the trampling intensity may have long-term negative effects on seagrass beds thus lead to the increase on phytoplankton and epiphytic biomass.

\section{Conclusion}

The epiphytes of seagrass is an important and dynamic component in seagrass beds. In the balance system, it does not have harmful effect on seagrass ecosystems. However, this present study suggest that human activities, such as trampling, could lead to the increasing of epiphytes cover on the seagrass beds and may contribute to the decrease of seagrass cover in Sepanjang Beach.

\section{Acknowledgements}

This research is funded by the PID research grants of Universitas Muhammadiyah Surakarta.

\section{References}

Borowitzka, M.A., P.S. Lavery, and M. van Keulen. 2006. Epiphytes of Seagrasses. In: Larkum, A.W.D., R.J. Orth, and C.M. Duarte (eds) Seagrasses: biology, ecology and conservation, pp 441-461. Springer, Dordrecht.

Cornelisen, C.D., and F.I.M Thomas. 2002. Ammonium uptake by seagrass epiphytes: Isolation of the effects of water velocity using an isotope label. Limnology and Oceanography vol. 47, pp $1223-1229$.

Eckrich, C.E., and J.G. Holmquist. 2000. Trampling in a seagrass assemblage: direct effects, response of associated fauna, and the role of substrate characteristics. Marine Ecology Progress Series vol. 201, pp 199-209.

Heijs, F.M.L. 1984. Annual biomass and production of epiphytes in three monospecific seagrass communities of Thalassia hemprichii (Ehrenb.) Aschers. Aquatic Botany vol. 20, pp 195-218.

Herrera-Silveira, J.A., J. Cebrian, J. Hauxwell, and P.R. Ramirez-Ramirez. 2010. Evidence of negative impacts of ecological tourism on turtlegrass (Thalassia testudinum) beds in a marine protected area of the Mexican Caribbean. Aquatic Ecology vol. 44 pp 23-31.

Jacobs, R.P.W.M., P.M. Hermelink, and G. van Geel. 1983. Epiphytic algae on eelgrass at Roscoff, France. Aquatic Botany vol. 15, pp 157- 173.

Long, W.J.L., R.G. Coles and L.J. McKenzie LJ. 1996. Deepwater seagrasses in northeastern Australia-How deep, how meaningful? In: Kuo, J., R.C. Phillips, D.I. Walker, and H. Kirkman (eds) Seagrass Biology, pp 41-50. University of Western Australia, Perth.

McKenzie, L.J., S.J. Campbell, and C.A. Roder. 2001. Seagrass-watch: manual for mapping \& monitoring seagrass resources by community (citizen) volunteers, 100pp, QFS, NFC, Cairns.

Patriquin, D. 1973. Estimation of growth rate, production and age of the marine angiosperm Thalassia testudinum Koenig. Caribbean Journal of Science vol. 13, pp 111-123.

Tanner, J.E., M. Theil, and D. Fotheringham. 2014. Seagrass Condition Monitoring: Encounter Bay and Port Adelaide. SARDI Aquatic Sciences, Adelaide.

74-The Percentage of... 